\title{
Role of Administrative Organization in Improving the Investment Efficiency of the Ministry of Investment in Sudan
}

\author{
Nandy Abuella Abdu Desougi, PhD \\ Assistant Professor \\ Amir Salim Elsheikh Algarrai, PhD \\ Associate Professor \\ Department of Administrative Sciences \\ Community College \\ Najran University \\ Najran - King Abdulaziz Road \\ Saudi Arabia \\ Shendi University \\ Sudan
}

\begin{abstract}
The study aimed to identify the situation of the administrative organization in the Ministry of Investment in Sudan, and analyze the organizational challenges and problems that faced them during the period $2012-2018$. In this study, deductive approach, analytical and descriptive methods were used (questionnaire, interview, and observation). A questionnaire was distributed to the sample of the study ( $n=125$ participants). 91completed questionnaire were retrieved which represented a response rate of $73 \%$.The results of the study revealed that the organizational structure of the Ministry of investment is characterized by vertical and horizontal relations, and the job description was revised from time to time to increase and specify the responsibilities for each job. Based on these results, the study provided a set of recommendations: the most important ones were reviewing the organizational structures and job descriptions by specialized committees, reviewing the job description periodically and supporting the investment department structure with academic and professional experts in training.
\end{abstract}

Keywords: administrative organization, investment efficiency, Ministry of Investment

\section{Introduction}

\subsection{Research Problem}

Although, the Republic of Sudan enjoys a strategic and attractive location and many natural resources, the situation of the Ministry of Investment exhibits deficiencies in the administrative organization of the Ministry. Accordingly, the study aims to identify the problems that the administrative organization of the Ministry of Investment encounters and the negative influences of such problems on the efficiency of investment. To address such deficiency, there is a need for a scientific study of administrative organization of the Ministry to identify the problems and propose solutions that enable the Ministry of Investment to achieve its objectives. Accordingly, the authors formulated the basic research question as 'what is the situation of the administrative organization of the Ministry of Investment in Republic of Sudan?'. Such a research question can be divided two questions :

a. Does the efficiency of the organizational structure attract investment?

b.Has the distribution of responsibilities and tasks led to increase in the size of investments?

\subsection{Research hypotheses}

The study is based on two main hypotheses that underlie the study, namely:

a. There is a statistically significant relation between the organizational structure and the efficiency of investment.

b. There is a statistically significant relation between distribution of responsibilities and tasks on the hand and the efficiency of investment on the other. 


\subsection{Significance of the Study}

The significance of the study lies in the scientific importance of contributing to the literature of administrative organization of the investment process. The empirical importance of the study lies in its account for the administrative organization in the investment process to which the state pays ample attention, Therefore, the findings and recommendations of the study are expected to assist decision maker in Sudan to develop the organizational aspect of the investment process in the country.

\subsection{Objectives of the Study}

The study aims to achieve the following objective:

a. To identify the administrative organization process of the Ministry of Investment.

b. To determine the organizational problems that encounter the Ministry of Investment through its organizational structures and job description, considering the principles and foundations of administrative organization.

c. To address the deficiencies in the administrative organization of the Ministry of Investment.

\section{Literature Review:}

Literature review deals with theoretical framework that the study draws on to achieve its objectives .

\subsection{Organization Process}

Organization is one of the most important operations of the administrative process in different institutions, and it was often ranked second after the planning process. Organization includes the proper and positive characterization of the tasks to be done in each job and the relationship of each job to another, which was set in the administrative structure. The word 'organization' is derived from the verb 'organize, which means etymologically 'to put things together in order', which can be described as structured and coordinated. The term organization is in harmony with the term 'system', which means the thing you organize is in order and of coherence, meaning what achieves consistency and compatibility is called organization (AL-Razi, 1986, p.667).

The term 'organization' in the science of management refers to the body of management without which the organization cannot implement the other functions of management (AL-Shawawrah, 2013, p. 137). It is defined by AL-Hawari (1996) as 'the process of identifying and compiling the work to be performed, following identification and delegation of responsibility and authority to enable people to work together efficiently to achieve goals' (P.42).

\subsection{Elements of Organization}

Organization includes activities performed by the organization or establishment to achieve its objectives, employees at the various scientific and technical levels, available potentials and resources( including materials, energy, finance, information and technology) policies and rules (mentioned in the plan that guide individuals to perform their work and use available resources), the structure or method of distribution of activities and tasks among individuals, identification of their job relationships, communication lines, people in charge of responsibility and decision-making (Ashibah, 2009, P.14).

\subsection{Principles, types and Characteristics of Organization}

Organization includes supervision, which means the number of individuals that the manager supervises personally and efficiently (AL-Hawasi and AL-Barzanji,2014, P.80). The unity of objective in the organization means that each execution or administrative unit should have a certain objective of direct relevance to the objective of the enterprise, meaning the objectives of the part of organization should be consistent with the objective of the whole organization. (AL-Taher,2009, P.47). The principle of division of work means the classification of the activities of the organization into main functional elements and further into sub elements in a way that the homogeneous activities are associated with each other in a functional relationship (AL-Shamaimary, et al., 2008, P.129). Besides, the principle of unity of order means that each employee has one chairman in which he or she receives the orders from one chairman (AL-Taher,2009, P.48).

The principle of equality of authority and responsibility means that each employee is responsible for doing his or her job tasks of and he or she is given the right in deciding the priorities of his or her work (AL-Shamimari, 2008, P.17). 
As for Job descriptions, it is the responsibilities, authorities and tasks that each employee should do in a certain institution and the assignment of his or her direct principal. Regarding job specifications, it means the qualifications required to fill a specific job, such as the degree of knowledge, experience and skills necessary to do his or her job efficiently (Al-Hawasi and Al-Barzanji, p. 80). Centralization of the organization denotes the concentration of decision in the senior management and whether the degree of delegation is limited or does not exist. (Al-Shammiri et al., 2008, p. 172). On the contrary, decentralization is characterized by a large degree of delegation of authority at all organizational levels and so subordinates are given greater freedom to act and make decisions (Dhiab, 2012, p. 317).

\subsection{Kinds of organization}

Formal organization is the process of grouping businesses into jobs and further into units, departments and managements. It is called formal organization because its grouping is done by project management irrespective of individuals and their relationships. Within the framework of the formal organization, there are specific levels of specialties, authorities and responsibilities in decision making in addition to deciding on problems, supervision and guidance. This sequence of organization fulfills the principle of coordination and the high authority of coordination can perform its functions.

As for informal organization, it is a natural grouping of individuals at work, which appears as a reaction to the social need of human being. It is limited in numbers as the grouping of its members is based on the selection of individuals, sharing close interests, attitudes and tendencies. One of its advantages is that it achieves satisfaction of needs for its member, which are not satisfied by formal organizations (Al-Hawasi and Al-Barzanji, 2014, p. 85 p. 86).

\subsubsection{Organizational Structure}

\subsubsection{Definition of Organizational Structure and its objectives}

Organizational structure shows different administrative levels in the organization, which includes the distribution of work among the different managements, departments, units and the formal relationships that link them and the scope of supervision in the organization (Al-Makhamarah, 2010, p. 49). The organizational structure aims to show the maps with its design in a way that make it possible to reach the desired objectives (i.e. integration of its components). It is taken for granted that an individual cannot perform all the work on his or her own. Therefore, the relations of individuals are based on cooperation with others to determine responsibilities and tasks, achieve coordination between efforts, make optimal use of the available resources, determine clearly the powers conferred to managements and departments and reduce the conflict. Among the elements of the organizational structure are presence of the various administrative units in the organization, the clarity of specialization and tasks, the scope of supervision, the line of authority and responsibility.

\subsubsection{Characteristics of the organizational structure}

The first characteristics of the organizational structure is complexity, which consists of three elements: horizontal specialization, which refers to the activities performed by the organization, professional job groups and the various specialties. When the number of organizational units and their divisions increased, the number and variety of jobs, specialties and organizational structure become complex and vice versa. As for the vertical division, which refers to the depth of the organizational structure. If the number of organizational levels increases, the organizational structure becomes more complex and vice versa. Geographical division refers to the extent of geographical distribution of the Organization's operations and activities. In doing so, the organizational structure becomes more complex when the number of units in different regions and locations increases.

The second characteristic is centrality, which means the concentration of important decision-making in one center or in senior management. Officially is concerned the extent to which the organization relies on laws, regulations, rules, instructions, decisions, procedures and detailed standards to guide and control the behavior, acts of the individual during his or her performance of his or her work. These laws, regulations and instructions are not necessarily written, but are sufficient to be followed by the workers (Wali, 2011, p.201).

\subsubsection{Forms of organizational structures}

a. Functional organizational Structure 
In such organizational structure, each job specialty is grouped into one department in a way that there is a financial manager, a production manager, a marketing manager, a human resource manager, etc. The deficiencies in this organizational structure a lack of flexibility, poor relationship between the various specialties and long chain of the organizational structure, meaning the existence of many levels of management. The advantages of this system lie in economic and centralization features.

\section{b. Product- based organizational structure}

This structure is classified according to types of activity, profession, commodity. The advantages of this structure are the possibility of making a good use of the specialized experience of in the products, complete coordination among the various processes such as purchase, production, storage and sale. As for the disadvantages of this structure is difficulty of getting managers of sufficient skills in all the operations of the establishment and the difficulty of coordination among multiple purchases.

\section{c. Geographical organizational structure}

In this structure, the operations are distributed on different locations. The advantages of this division lie in the operational managers' knowledge of these locations due to their accurate information about such locations and the possibility of making decisions as quickly as possible any event. One disadvantage of this structure is the possibility of managers' abuse of the authorities given to them in area of their work.

\section{d.Customer-based organizational structure}

In this type of structure, the organization has a variety of clients (e.g. wholesale and retail). One advantages of this structure is that it is possible to coordinate all activities of relevance to a certain type of customers easily without having multiple departments. The disadvantages of this structure lie in the possibility of absence of asymmetry of the organization's transactions. If a department decreases the prices to its own customers, other customers in other departments may feel anger.

\section{e. Matrix- organizational structure}

In such a structure, the employees are classified according to jobs in the functional organizational structure and the selection of a principal for every product. The benefits of this structure are its combination for several characteristics of both the functional and sectoral organization. One of its disadvantages is the difficulty of organizing work among employees of two heads (Wali, 2010, p. 29 p. 33).

\subsection{Investment}

The term 'investment' is derived from the verb 'invest', which means 'to spend money, time, or energy on something', especially for some benefit or purpose. Investment in the language of science is "sacrificing to satisfy a current consumer's desire to get greater satisfaction in the future" (Matar, 2009, p. 21). Investment basically aims to use cash surpluses more efficiently or to create better business relationships through direct influence of an organization in which these surpluses are invested. The investment objectives differ according to the organization that makes the investment (Siam, 1997, p. 24).

The efficiency of investment refers to the degree to which management succeeds in exploiting available organizational resources. When there is less wastefulness in the use of organizational resources, the organization become more efficient (Mustafa, 2005, p. 24). The efficiency of investment is associated with the efficiency of the organizational structure, meaning achieving proper coordination and proper control over performance levels. It is possible to judge the efficiency of the organization via applying the principles of management (Al-Garrai, 2016, p. 10).

\section{Previous studies}

The concern of this section is to present the previous studies that are of relevance to this study, which will be presented in terms of objectives, methods and findings. AL-Manqash (1999) conducted a study in which she aimed to analyze the situation of the administrative organization in female student centers at Saudi universities, according to the principles and foundations of administrative organization to identify the organizational problems that face such centers and the effect of such problems on administrative performance in these centers. The author used descriptive approach to analyze the administrative organization of the female student centers, including organizational structures, job descriptions, regulations of the Higher Education Council, universities and operating procedures. 
The study found absence of a unified administrative organization in the female student centers, which are controlled by bureaucratic organization. Besides, the organizational structures are vertical and have many administrative levels. It was found absence of organizational guides that describe the jobs, and their organizational relation with their administrative units, emergence of conflicts, transcending administrative levels, the centrality of decision making and planning in the senior management of the university and unclarity of tasks and responsibilities

The author recommended formation of a specialized committee of experts in the Department of Higher Education to implement the proposals regarding restructuring student centers, organizational relations, job descriptions, laws and regulations. She also recommended that administrative organization should be flexible, allowing continuous and self-development and coping with continuous and rapid changes. Shaaban (2007) studied the developments that occurred in the organizational structure of the Palestinian ministries and the impact of such development on the administrative efficiency of the ministries. The author employed descriptive approach, depending on the secondary and primary sources. A questionnaire of 80 items was designed to cover the study's hypotheses. The sample of the study is star field sampling, which consists of 500 out of 3118 employees, whose administrative levels ranged from a vice minister to the head of department. The questionnaire was analyzed through SPSS program. The author found that changes were made in the organizational structures of the ministries without indepth studies. Besides, such changes contradict the objectives of the strategies of these ministries and the organizational structures were designed by non-specialists and have fallen short of the required level of using technology. Besides, he found changes in organizational structures did not help to improve the performance of existing staff by creating specialized training programs and not even using competitions to select the best competent managers. The most important recommendations were reformulating the mission and objectives of the Palestinian ministries and their strategies to design appropriate organizational structures and job descriptions to avoid duplication and overlapping of authorities, establishment of a training center in which employees are continuously trained to improve their job performance, working to keep abreast of technological developments due to the effort in the decision-making process and the development of organizational structures in accordance with this technology and the objectives of the ministries.

Al-Qutaibi (2006) investigated the investment procedures in the General Authority of Investment in Yemen to identify the nature of these procedures and their effect on the growth of investment during the period 1992-2004. The research problem lies in whether the General Investment Authority fulfills the tasks assigned to the investment process in Yemen. The author found weakness in the efficiency of the performance and institutional capacity of the General Authority for Investment in the process of attracting investments to Yemen, a lack of coordination and communication between the General Authority for Investment and some government institutions concerned with implementing investment projects. He recommended to establish administrative and organizational units that will assist the efficiency and effectiveness of performance in the General Authority for Investment, adoption of effective and practical mechanisms for coordination and communication between the General Authority for Investment and the relevant parties with investment transactions to facilitate and simplify the procedures of implementing investment projects registered with the Authority, paying attention to the training of the staff of the Authority and increase of the specialized courses on the tasks assigned to the general Authority of Investment.

\section{Research Methodology}

\subsection{Research Method}

The author followed the descriptive analytical method in which the case study was used, which provided the necessary information and showed the changes required by the comprehensive study, which leads to the exploration of new fields of research and hypotheses for further studies. The descriptive approach clarifies the various advantages of statistical results, which led to the current results.

\subsection{Resources of Data}

4.2.1. Primary Sources: Data and information obtained from the population of the study (i.e. employees of the Ministry of Investment), which was collected via questionnaire, interview and observation. 
4.2.2. Secondary Sources: These include sources, references and documents in the field of management, especially business administration, investment field, scientific journals' papers, reports and publications of the Ministry of Investment in addition to the dissertations and theses and other relevant studies.:

\section{Data Analysis}

\subsection{Statistical Analysis}

To answer the questions of study, the statistical data were analyzed using the SPSS, namely methods of frequency and Chi-Square, which were used to determine whether there are significant differences among the mean responses of the sample on the role of administrative organization in improving the investment efficiency in Ministry of Investment in Sudan.

\section{2. yduts eht fo noitcudnoC}

The author depended on the questionnaire as a main tool to collect the data on the sample of the study. The questionnaire included a formal letter to the Ministry of Investment, explaining the subject and purpose of the study. The questionnaire has two elements: personal information, including (gender, age, social status and qualification, specialization, years of experience, position). The name of the institution (Ministry of Investment) was mentioned in the questionnaire. The second elements of the questionnaire contain set of items that a respondent should answer, according to the five-dimensional Likert scale (Strongly Agree, Agree, Neutral, Disagree and Strongly Disagree). The items of the questionnaire were distributed according to the hypotheses of the study.

\subsection{Limitations of the study}

Place: Khartoum State, Presidency of the Ministry of Investment in Sudan.

Human domain: Employees of the Ministry of Investment.

Time: $2012-2016$

\subsection{Analysis of Sample}

The sample size was approximate for each group, depending on the size of the community in that group. Table (1) shows the number of questionnaires distributed to the sample. 125 questionnaires were distributed, among these questionnaires only 91 were returned.

Table (1) Distribution of Sample according to Position\

\begin{tabular}{lllll}
\hline No. & Position & $\begin{array}{l}\text { Distributed } \\
\text { Numbers }\end{array}$ & $\begin{array}{l}\text { Returned } \\
\text { Numbers }\end{array}$ & Percentage \\
\hline & Director of the Department & 15 & 10 & $\% 66$ \\
& Executive Director of the Office & 4 & 2 & $\% 50$ \\
Chairman of the Unit & 10 & 8 & $\% 80$ \\
Office Manager & 2 & 1 & $\% 50$ \\
& Programmer & 4 & 2 & $\% 50$ \\
Senior Inspector & 25 & 19 & $\% 76$ \\
& Assistant Inspector & 10 & 7 & $\% 70$ \\
& Secretary & 5 & 3 & $\% 60$ \\
& Inspector & 25 & 15 & $\% 96$ \\
& Others & 25 & 24 & $\% 72$
\end{tabular}

\subsection{Results of the statistical analysis of the characteristics of the sample}

a. Gender

Table (2) Frequency and percentages of sample according the gender

\begin{tabular}{|l|l|l|l|}
\hline No. & Gender & Frequency & Percentage \\
\hline 1 & Male & 44 & $51.8 \%$ \\
\hline 2 & Female & 41 & $48.2 \%$ \\
\hline Total & 85 & $100 \%$ \\
\hline
\end{tabular}


Table (2) above shows that the number of males approximately equals number of females, which shows no b. egA distinction in male and female employment

Table (3) Frequency and percentages of sample according the age

\begin{tabular}{|l|l|l|l|}
\hline No & Age & Frequency & Percentage \\
\hline & Less than 30 & 21 & $23.9 \%$ \\
\hline & 30 - less than 35 & 25 & $28.4 \%$ \\
\hline & 35 - less than 40 & 20 & $22.7 \%$ \\
\hline & 40 -less than 50 & 7 & $8 \%$ \\
\hline & 50 -more & 15 & $\% 17$ \\
\hline Total & 88 & $\% 100$ \\
\hline
\end{tabular}

In Table (3) the age group 30-50 years constituted most of the sample, which revealed that the Ministry of Investment targeted youth, resigning those who are above the age of 50 voluntarily.

c. Qualification

Table (4) Frequency and percentages of sample according to qualification

\begin{tabular}{|l|l|l|l|}
\hline No. & Qualification & Frequency & Percentage \\
\hline & Secondary school & 7 & $7.8 \%$ \\
\hline & Middle Diploma & 10 & $11.1 \%$ \\
\hline & Bachelor & 38 & $42.2 \%$ \\
\hline & Higher diploma & 4 & $4.4 \%$ \\
\hline & Master & 31 & $34.4 \%$ \\
\hline Total & & 90 & $100 \%$ \\
\hline
\end{tabular}

Table (4) shows that the Ministry is interested in recruiting qualified individuals whose number reached (38), constituting $42 \%$ of the sample, holding higher degrees (master and higher diploma). Their responses will support the study, meaning their opinions will contribute to the achievement of sound scientific results, especially if combined with practical experience. However, doctorate and fellowship did not exist.

d. Specialization

Table (5) Frequency and percentages of sample according to specialty

\begin{tabular}{|l|l|l|l|}
\hline No. & Specialization & Frequency & Percentage \\
\hline & Business Administration & 22 & $26.5 \%$ \\
\hline & General Management & 3 & $3.6 \%$ \\
\hline & Economics & 8 & $9.6 \%$ \\
\hline & Statistics & 1 & $1.2 \%$ \\
\hline & Literature & 4 & $4.8 \%$ \\
\hline & English- Arts & 1 & $\% 1.2$ \\
\hline & Media & 5 & $6 \%$ \\
\hline & Media and Public Relations & 2 & $2.4 \%$ \\
\hline & Economics & 5 & $6 \%$ \\
\hline & Economics Political Sciences & 2 & $2.4 \%$ \\
\hline & Planning & 1 & $1.2 \%$ \\
\hline & Planning and Development & 1 & $1.2 \%$ \\
\hline & Translation & 1 & $1.2 \%$ \\
\hline & Marketing and sale management & 2 & $2.4 \%$ \\
\hline & Computer & 11 & $13.3 \%$ \\
\hline & Islamic Studies & 1 & $1.2 \%$ \\
\hline & International Relation & 1 & $1.2 \%$ \\
\hline & Law & 2 & $2.4 \%$ \\
\hline & English Language & 2 & $2.4 \%$ \\
\hline & Accounting & 6 & $7.2 \%$ \\
\hline
\end{tabular}




\begin{tabular}{|l|l|l|l|}
\hline & Banking & 2 & $2.4 \%$ \\
\hline Total & 91 & $100 \%$ \\
\hline
\end{tabular}

Table (5) shows clear diversity in the specialties in the Ministry of Investment, which indicates that the Ministry continues and copes with developing its structure.

e. Years of experience

Table (6) Frequency and percentages of sample according to Years of Experience

\begin{tabular}{llll}
\hline No & Year of Experience & Frequency & Percentage \\
\hline 1 & Less than 5 Years & 30 & $37.5 \%$ \\
2 & 5-10 Years & 14 & $17.5 \%$ \\
3 & 10- more & 36 & $45 \%$ \\
Total & & 80 & $100 \%$
\end{tabular}

Table (6) shows $45 \%$ of the sample has a long experience of more than ten years, the number of the participants of 10 years or more are (36), constituting $45 \%$ of the sample investigated, which reflected the stability and high accumulated experience of the staff of the Ministry.

a. Position

Table (7) Frequency and percentages of sample according to position

\begin{tabular}{|l|l|l|l|}
\hline No. & Position & Frequency & Percentage \\
\hline 1 & Department Director & 10 & $14.9 \%$ \\
\hline 2 & Executive Office Director & 2 & $3 \%$ \\
\hline 3 & Unit Chairman & 8 & $\% 11.9$ \\
\hline 4 & Office Manager & 1 & $1.5 \%$ \\
\hline 5 & Programmer & 2 & $3 \%$ \\
\hline 6 & Senior Inspector & 19 & $28.4 \%$ \\
\hline 7 & Assistant Inspector & 7 & $10.4 \%$ \\
\hline 8 & Secretary & 3 & $4.5 \%$ \\
\hline 9 & Inspector & 15 & $22.4 \%$ \\
\hline Total & & 67 & $100 \%$ \\
\hline
\end{tabular}

Table (7) shows that the distribution of the questionnaire was based on the position of the participants, having direct relationship with the Ministry's departments and the implementation of its policies. Most participants were inspectors (19), constituting $(28.4 \%)$ of the sample. The authors could interview the directors of the departments to fill the questionnaire. The ministry is still in the process of changing the structure from the National Investment Authority to the new structure in the name of the Ministry of Investment.

b.Job position

Table (8) Frequency and percentages according to job Position

\begin{tabular}{|l|l|l|l|}
\hline No. & Job Position & Frequency & Percentage \\
\hline & Department Director & 1 & $10 \%$ \\
\hline & Media & 2 & $20 \%$ \\
\hline & Trainer & 2 & $20 \%$ \\
\hline & Public Prosecutor & 1 & $10 \%$ \\
\hline & Supervisor & 2 & $20 \%$ \\
\hline & Administrative Supervisor & 2 & $20 \%$ \\
\hline Total & 10 & $100 \%$ \\
\hline
\end{tabular}

Table (8) shows that the distribution of the questionnaire was based on job position of the participants, having direct relationship with the Ministry's departments and the implementation of its policies. Most participants of the study were supervisors (19), constituting (20.\%) of the sample. The percentages of supervisors, department managers and department managers are normal according to their numbers. 
Table (9) Validity and Reliability of participants' responses

\begin{tabular}{lll}
\hline Hypothesis & Reliability & Validity Percentage \\
\hline 1 & $\% 83$ & $\% 91$ \\
2 & $\% 80$ & $\% 89$ \\
All hypotheses & $\% 85$ & $\% 92$
\end{tabular}

Table (9) shows that all coefficients of reliability and validity of the sample's responses to the questions of the hypotheses of the study are greater than $(85 \%)$, indicating that the questionnaire is characterized by a high degree of reliability and validity, which achieves the objectives of the study.

5.7. Participants' responses to the questionnaire

Table (10) participants' responses on 1st hypothesis

\begin{tabular}{|c|c|c|c|}
\hline Items & Level & Frequency & Percentage \\
\hline \multirow{5}{*}{$\begin{array}{l}\text { The organizational structure of the Ministry is } \\
\text { flexible }\end{array}$} & Strongly Disagree & 2 & $2.2 \%$ \\
\hline & Disagree & 9 & $10.0 \%$ \\
\hline & Neutral & 15 & $16.7 \%$ \\
\hline & Agree & 39 & $43.3 \%$ \\
\hline & Strongly Agree & 25 & $27.8 \%$ \\
\hline \multirow{5}{*}{$\begin{array}{l}\text { The organizational structure of the Ministry } \\
\text { includes all management units. }\end{array}$} & Strongly Disagree & 0 & $0.0 \%$ \\
\hline & Disagree & 9 & $10.2 \%$ \\
\hline & Neutral & 14 & $15.9 \%$ \\
\hline & Agree & 35 & $39.8 \%$ \\
\hline & Strongly Agree & 30 & $34.1 \%$ \\
\hline \multirow{5}{*}{$\begin{array}{l}\text { The organizational structure of the Ministry is } \\
\text { clear for all employees. }\end{array}$} & Strongly Disagree & 4 & $4.4 \%$ \\
\hline & Disagree & 12 & $13.3 \%$ \\
\hline & Neutral & 6 & $6.7 \%$ \\
\hline & Agree & 42 & $46.7 \%$ \\
\hline & Strongly Agree & 26 & $28.9 \%$ \\
\hline \multirow{5}{*}{$\begin{array}{l}\text { The organizational structure shows vertical } \\
\text { and horizontal relationships. }\end{array}$} & Strongly Disagree & 3 & $3.4 \%$ \\
\hline & Disagree & 10 & $11.2 \%$ \\
\hline & Neutral & 15 & $16.9 \%$ \\
\hline & Agree & 42 & $47.2 \%$ \\
\hline & Strongly Agree & 19 & $21.3 \%$ \\
\hline
\end{tabular}

The results of analysis, as in Table (10), shows the following results: For the first item (the organizational structure of the ministry is flexible), 39 of the sample (constituting 43.3\%) responded to with agreement.

For the second item (the administrative structure of the ministry includes all administrative units), 35 participants $(39.8 \%)$ responded with agreement. For the third item (organizational structure is clear for employees), 42 participants (46.7\%) responded with agreement. For the fourth item, (organizational chart shows vertical and horizontal relations), 42 participants (47.2) responded with agreement. In doing so, the first hypothesis items were answered with agreement.

Table (11) participants' responses on 2nd hypothesis

\begin{tabular}{|l|l|l|l|}
\hline Items & Level & Frequency & Percentage \\
\hline Tasks were distributed among employees fairly. & $\begin{array}{l}\text { Strongly } \\
\text { Disagree }\end{array}$ & 4 & $4.4 \%$ \\
\cline { 2 - 4 } & Disagree & 10 & $11.1 \%$ \\
\cline { 2 - 4 } & Neutral & 6 & $6.7 \%$ \\
\cline { 2 - 4 } & Agree & 39 & $43.3 \%$ \\
\cline { 2 - 4 } & $\begin{array}{l}\text { Strongly } \\
\text { Agree }\end{array}$ & 31 & $34.4 \%$ \\
\hline Job description illustrates the responsibilities of every job. & $\begin{array}{l}\text { Strongly } \\
\text { Disagree }\end{array}$ & 2 & $2.2 \%$ \\
\cline { 2 - 4 } & Disagree & 10 & $11.1 \%$ \\
\cline { 2 - 4 } & Neutral & 20 & $22.2 \%$ \\
\hline
\end{tabular}




\begin{tabular}{|c|c|c|c|}
\hline & Agree & 36 & $40.0 \%$ \\
\hline & $\begin{array}{l}\text { Strongly } \\
\text { Agree }\end{array}$ & 22 & $24.4 \%$ \\
\hline \multirow[t]{5}{*}{$\begin{array}{l}\text { The job description is reviewed from time to time to increase or } \\
\text { specify the responsibilities of each job. }\end{array}$} & $\begin{array}{l}\text { Strongly } \\
\text { Disagree }\end{array}$ & 4 & $4.4 \%$ \\
\hline & Disagree & 17 & $18.9 \%$ \\
\hline & Neutral & 13 & $14.4 \%$ \\
\hline & Agree & 32 & $35.6 \%$ \\
\hline & $\begin{array}{l}\text { Strongly } \\
\text { Agree }\end{array}$ & 24 & $26.7 \%$ \\
\hline \multirow[t]{5}{*}{ The job description is flexible in determining responsibilities } & $\begin{array}{l}\text { Strongly } \\
\text { Disagree }\end{array}$ & 3 & $3.3 \%$ \\
\hline & Disagree & 24 & $26.7 \%$ \\
\hline & Neutral & 12 & $13.3 \%$ \\
\hline & Agree & 26 & $28.9 \%$ \\
\hline & $\begin{array}{l}\text { Strongly } \\
\text { Agree }\end{array}$ & 25 & $27.8 \%$ \\
\hline
\end{tabular}

Table (10), shows the following results:

For the first item (Tasks were distributed among employees fairly), 39 of the sample (constituting 43.3\%) responded with agreement. For the second item (Job description illustrates the responsibilities of every job), 36 participants (40\%) responded with agreement. For the third item (The job description is reviewed from time to time to increase or specify the responsibilities of each job.), 23 participants (35.6\%) responded with agreement. For the fourth item, (job description is flexible in determining responsibilities), 26 participants (28.9\%) responded with agreement. In doing so, the second hypothesis was answered with agreement.

\subsection{Testing Hypotheses}

\subsubsection{Discussion of the first Hypothesis}

The first hypothesis (There is relation of a statistical significance between organizational structure and investment effeminacy), aims to identify whether the lack of an efficient organizational structure leads to poor investment. To verify this issue, the authors should examine the attitude of the sample towards the first hypothesis, which was done via calculating the frequency of the responses of the sample on each item of the hypothesis, and then on the all hypotheses. Table (12) summarizes the test results.

Table (12) Chi-square results of participants' responses to items of the 1st hypothesis

\begin{tabular}{|l|l|l|l|l|l|}
\hline No & Items & Chi-Square Value & P. Value & Sig. & Level \\
\hline 1 & $\begin{array}{l}\text { Tasks were distributed among } \\
\text { employees fairly. }\end{array}$ & $\% 43.3$ & 0.000 & $\begin{array}{l}\text { Statistically } \\
\text { Significant }\end{array}$ & Agree \\
\hline 2 & $\begin{array}{l}\text { Job description illustrates the } \\
\text { responsibilities of every job }\end{array}$ & $\% 39.8$ & 0.000 & $\begin{array}{l}\text { Statistically } \\
\text { Significant }\end{array}$ & Agree \\
\hline 3 & $\begin{array}{l}\text { The job description is reviewed from } \\
\text { time to time to increase or specify the } \\
\text { responsibilities of each job. }\end{array}$ & $\% 46.7$ & 0.000 & $\begin{array}{l}\text { Statistically } \\
\text { Significant }\end{array}$ \\
\hline 4 & $\begin{array}{l}\text { The job description is flexible in } \\
\text { determining responsibilities. }\end{array}$ & $\% 47.2$ & 0.000 & $\begin{array}{l}\text { Statistically } \\
\text { Significant }\end{array}$ & Agree \\
\hline
\end{tabular}

The results in Table (12) can be interpreted as follow:

The P-value of the chi- square test for significant differences among the responses of the sample for the first, second, third, and fourth items of the first hypothesis is (0.000), which is smaller than 0.01. Such figures revealed the validity of the significant differences among the sample members in favor of agreement response, indicating that:

a. The organizational structure of the ministry is flexible, which means that it is adjustable or developed according to the requirements of work.

b. The specialized committee responsible for design of the organizational structure of the Ministry considers all administrative units in the organizational structure to cover all administrative units. 
c. Departments of the Ministry informed the staff of its organizational structure and the location of each employee and the unit to which he or she belongs.

d. The structure of the Ministry of Investment illustrates the lines of authority and responsibility for the staff from the senior management to the minimum management with the knowledge that the authority of main center of the Ministry is centralized and part of authority sub-centers is mandated

Table (13) Mean Score of the first hypothesis items

\begin{tabular}{|c|c|c|}
\hline First Hypothesis & P-Value & Level \\
\hline $\begin{array}{l}\text { There is a statistically significant relationship } \\
\text { between organizational structure and investment } \\
\text { efficiency, } \\
\text { Table (13) demonstrates the mean score of the first } \\
\text { participants' responses of all the items of first hyp } \\
\text { agreement. } \\
\text { Table (14) Frequency of the sample's responses on } t\end{array}$ & $\begin{array}{l}3.84170 .000 \\
\text { hypothesis's items, pointin } \\
\text { thesis is }(0.000) \text {, which i } \\
\text { e first hypothesis }\end{array}$ & $\begin{array}{l}\text { Statistically Agreement } \\
\text { Significant } \\
\text { out that the P-value for all the } \\
\text { smaller than }(0.01) \text {, in favor of }\end{array}$ \\
\hline Final Assessment & Frequency & Percentage \\
\hline Strongly Disagree & 2 & $2.2 \%$ \\
\hline Disagree & 5 & $5.6 \%$ \\
\hline Neutral & 21 & $23.3 \%$ \\
\hline Agree & 45 & $50 \%$ \\
\hline Strongly Agree & 17 & $18.9 \%$ \\
\hline Total & 90 & $100 \%$ \\
\hline
\end{tabular}

Table (14) shows the following findings:

a. $\quad 18.89 \%$ of the sample strongly agreed with all the items of the first hypothesis.

b. $\quad 50 \%$ of sample agreed with all the items of the first hypothesis.

c. $\quad 23.33 \%$ of the sample' responses were neutral.

d. Only $5.56 \%$ of the sample disagreed with all the items of the first hypothesis.

e. Only $2.22 \%$ of the sample strongly disagreed with all the items of the first hypothesis.

Based on such figures, the authors concluded that the items of the first hypothesis are mostly answered positively, which showed the hypotheses is validated and so the organizational structure is flexible and it was designed according to a specialized committee that carefully examined how to design the organizational structure and job description, clarifying the lines of authority and responsibility for each job and review the structure from time to time; thus, validating the hypothesis.

\subsubsection{Discussion of the Second hypothesis}

The second hypothesis states the presence of a statistically significant relationship between responsibilities and tasks on the one hand and the efficiency of investment on the other, which aims to recognize the way of distribution of responsibilities and tasks (job description) among all employees of the Ministry based on the organizational structure. It also aims to recognize whether the Ministry informs the employees through guides with the job description of each job so that they recognize and fulfill the tasks assigned to them to achieve an efficient investment. To check such as issue, the authors should know the sample's attitudes towards each item of the second hypothesis via calculating the frequency of the participants' responses on each item of the hypothesis, and then the hypothesis. Table (15) summarizes the test results. 
Table (15) Chi-square results of participants' responses to items of the $2^{\text {nd }}$ hypothesis

\begin{tabular}{|c|c|c|c|c|c|}
\hline No & Questions & $\begin{array}{l}\text { Chi-square } \\
\text { value }\end{array}$ & $\begin{array}{l}\text { P- } \\
\text { value }\end{array}$ & Sig. & $\begin{array}{l}\text { Scale } \\
\text { type }\end{array}$ \\
\hline 1 & The duties are distributed to employees fairly. & $28.9 \%$ & 0.000 & $\begin{array}{l}\text { Statistically } \\
\text { significant }\end{array}$ & $\mathrm{A}$ \\
\hline 2 & $\begin{array}{l}\text { The Job Description guide is written and communicated to staff } \\
\text { and explains the responsibilities of each job. }\end{array}$ & $43.3 \%$ & 0.000 & $\begin{array}{l}\text { Statistically } \\
\text { significant }\end{array}$ & A \\
\hline 3 & $\begin{array}{l}\text { The job description is reviewed from time to time to increase or } \\
\text { specify the responsibilities of each job. }\end{array}$ & $35.6 \%$ & 0.000 & $\begin{array}{l}\text { Statistically } \\
\text { significant }\end{array}$ & SA \\
\hline 4 & The job description is flexible in determining responsibilities. & $40 \%$ & .0010 & $\begin{array}{l}\text { Statistically } \\
\text { significant }\end{array}$ & SA \\
\hline
\end{tabular}

In Table (15), the P-value of the chi- square test for significant differences among the responses of the sample for the first, second, third, and fourth items of the second hypothesis is (0.000), which is smaller than 0.01. Such figures revealed the validity of the significant differences among the sample members in favor of agreement response, indicating that:

a. The chair of the work distributed the tasks among the staff fairly in his or her unit.

b. The staff was informed with job description and they are familiar with their jobs' tasks.

c. The job description is reviewed from time to time at least every three years to increase and specify each job based on the recommendations of the committee of designing the organizational structure.

d. The job description is flexible.

Table (16) Mean score of the first hypothesis items

\begin{tabular}{|l|l|l|l|l|}
\hline Hypothesis & $\begin{array}{l}\text { Mean } \\
\text { Score }\end{array}$ & $\begin{array}{l}\text { P- } \\
\text { Value }\end{array}$ & Sig. & Scale type \\
\hline $\begin{array}{l}\text { There is a statistically significant relationship between } \\
\text { responsibilities, tasks and the efficiency of investment. }\end{array}$ & 3.9444 & 0.000 & $\begin{array}{l}\text { Statistically } \\
\text { significant }\end{array}$ & Agreement \\
\hline
\end{tabular}

Table (16) demonstrates the mean score of the items of the second hypothesis, pointing out that the P-value for all the participants' responses of all the items of first hypothesis is $(0.000)$, which is smaller than (0.01), in favor of agreement.

Table (17) Frequency of the sample responses on the second hypothesis

\begin{tabular}{|l|l|l|}
\hline Final Assessment & Frequency & Percentage \\
\hline Disagree & 5 & $5.6 \%$ \\
\hline Neutral & 18 & $20 \%$ \\
\hline Agree & 51 & $56.7 \%$ \\
\hline Strongly Agree & 16 & $17.8 \%$ \\
\hline Total & 90 & $100 \%$ \\
\hline
\end{tabular}

Table (17) above shows the following findings:

a. $\quad 17.8 \%$ of the sample strongly agreed with all the items of the first hypothesis.

b. $\quad 56.7 \%$ of sample agreed with all the items of the first hypothesis.

c. $20 \%$ of the sample' responses were neutral

d. Only 5.56\% of the sample disagreed with all the items of the first hypothesis.

derewsna neeb evah siehtopyh dnoces eht fo smeti eht lla taht dedulcnoc srohtua eht, serugif sesht no desaB

T .detadilav saw sisetopyh eht os dna ylevititosphe distribution of tasks and responsibilities and the employees' knowledge of their tasks serve the investor and thus contributes to raising the efficiency of investment. Accordingly, the second hypothesis was validated and accepted.

\section{Findings and Recommendations}

6.1. Findings

1. The organizational structure of the Ministry of Investment demonstrates vertical and horizontal relations through the lines of authority and responsibility and their sequence from the top management of the 
hierarchy to the lower management, considering the grouping of similar activities and tasks in specialized managements and departments.

2. The organization of the Ministry shows flexibility and flow of information among its units and bodies in a way that integrates these units and bodies.

3. The job description is reviewed from time to time to increase or specify the responsibilities of each job.

4. Guide of job description is written and informed to the employees.

5. The organization considers the principle of specialty so that each job level is given their true weights according to the work size, load, tasks and responsibilities.

6. Employees' tasks are distributed fairly.

\subsection{Recommendations}

1. Specialized committees should review organizational structures and job descriptions.

2. The organizational structure of the Ministry of Investment should be provided with specialized academic and professional experts to contribute to the training process.

3. Modern technologies should be used in the communication among the branches of the Ministry in different locations.

4. The organization of the Ministry of Investment should be based on the principle of the qualitative division of the work.

5. The departments of the Ministry of Investment should be built according to the nature and work quality.

6. The organization of the Ministry of Investment should consider the principle of specialty to give the job levels their true weights according to the size of works, load, tasks and responsibilities.

\section{Acknowledgement}

Thanks to the top Management of the Ministry of Investment in Sudan and its staff who agreed to participate in this study. Thanks are also due to Dr. Mutahar Al-Sayed for his assistance with suggestions and translation.

\section{References}

Abdulsalam. Shaaban, N. (2007). Evolution of the organizational structures of the Palestinian ministries in the Gaza Strip and their effect on administrative efficiency, Journal of the Islamic University,15(5),

Al-Hawari, A. (1996). Organization of theories, structure, behavior and practice, Cairo: Ain Shams Library.

Al-Manqash, S. (2009). Administrative organization of student's centers in Saudi Universities, Journal of Educational Sciences, Institute of Educational Studies, 17 (2), 149-201.

Al-Garrai, M. (2016). Time wasters in organization. Journal of Community College, King Saud University 5(15), $36-42$.

Al-Qutaibi, N. (2006). The Impact of procedures on investment Growth, A study on the general investment authority, Khartoum. (Unpublished Master Thesis), Faculty of Administrative Sciences, Omdurman Islamic University, Sudan.

Al-Razi, M. (1986). Mokhtar Al-Sihah (1st Ed). Beirut: Lebanon Library.

Al-Shammari (2008). Principles of business administration(4Ed), Saudi Arabia: Obeikan Publishing.

Al-Shawawrah, F. (2013). Principles of Business Administration: Concepts of theory and practical applications (1st Ed). Amman: Dar Al-Manahej for Publishing and Distribution.

Al-Zaher, M. (2009) Administrative systems: concept, principles, fundamentals \& importance (1st Ed.). Jordan: The World of Modern Books.

Arabian, Y. (2008). Modern management concepts (1st Ed). Jordan: Dar Yafa for Publishing and Distribution.

Diab, F. (2012) Business Administration and manager jobs in contemporary institutions (1st Ed). Jordan: Dar Safa for Printing, Publishing and Distribution.

Matar, M. (2009). Investment management (5Ed). Jordan: Dar Wael Publishing and Distribution. Shamout, M. \&Kenjo K. (2008). Foundations of Investment. Cairo: United Arab Marketing and Supplies Company.

Siyam, A. (1997) Principles of Investment, Jordan: Dar Al-Manahij for Publishing and Distribution.

Wali, A. (2011). Building organizational structures. Iraq: D.N. 